\title{
Historicization of Homeless Spaces: The Seoul Train Station Square and the House of Freedom
}

\author{
Jesook Song
}

University of Toronto

\begin{abstract}
This paper historicizes "deserving" citizenship of South Korea by tracing spatial changes and meanings of two places: Seoul Train Station Square and a former textile factory renovated to a homeless shelter. Both have been emblematic space where the most homeless people were populated since the break of the Asian Debt Crisis. However, each place embodies different history of "deserving" citizenship in a complementary way. The square, a politically charged literary and physical topography, became a location of protecting "normal" citizen from potentially violent homeless people. The factory, a spatial marker for the state regulation of laborer, became a site to promote the benevolent image of welfare state for protecting homeless people through a demarcation of short-term street living people - as "deserving" homeless citizens-from long term street living people. The embedded history in two places would be the transition of developmental state towards the welfare state that shifted its capitalist state focus from labor/economic policies to welfare policy: neoliberalization of state governance in South Korea. In concrete, this paper examines how homeless people emerged as new welfare subjects in an urban landscape; how only short-term street living people were selected as
\end{abstract}


proper; how various social agents were involved in the process of implementing homeless policies; and how dualistic capitalist control over labor power, such as regular workers and surplus laborer, was imposed. [Keywords: South Korea, homelessness, "deserving" citizenship, labor power, spatial construction of history, liberal social governance]

The spaces of cities are the spaces where the hegemonic struggles over liberalism are now being fought. Whose liberalism? Whose hegemony? The socially revisionist liberalism of "well-being" or the neo-liberal mantra of "international competitiveness"? There are clearly new alliances, new struggles, new forms of subject formation, new forms of consciousness, new narratives, and new and ongoing imperatives to rework the ever shifting articulations of state and nation, and nation and city. (Mitchell 2004:19)

T his paper attempts to make sense of homeless policy in South Korea during the Asian Debt Crisis (henceforth, the Crisis) by examining the transformation of two symbolically charged physical spaces in Seoul: the Seoul Train Station Square (henceforth, the Square) and the House of Freedom, the former Pangnim Factory. I treat the Square and the House of Freedom as spatial foci for evolving homeless scenes and policy as well as the sites for liberal and neoliberal historicity. Following two theoretical paradigms, I define neoliberalism as a politico-economic and socio-cultural logic that operates through diverse social actors to engineer certain forms of social governance. One is Foucault's and Foucauldians' conceptualizations of neoliberalism as an advanced form of liberalism that borrows from liberalism's core ideas of individuation and privatization (Foucault 1990, 1991; Burchell 1991; Barry et al. 1996; Dean 1999). The other comes from leftist cultural and political theorists who analyze the connection between liberalism/neoliberalism and global capitalism (Hall 1984, Clarke 2004, Jessop 1994, Peck 2001, Peck and Theodore 2001, Kawashima 2005a). Moreover, I posit that by separating neoliberalism from liberalism one fails to acknowledge that state power is not literally reduced under neoliberalism but is rather modified and sustained in the form of social governance through technologies that "govern at a distance" (Rose 1990, 1999). My work builds on ethnographies that show urban space as a problematic and symptomatic location for and the complex product of capitalist assemblage in its conflict and crisis (Anagnost 2004, Li 2002, Mitchell 2004, 
Nelson 2000, Ong and Collier 2005, Strathern 2000). Influenced by those ethnographers of discourse and thematic, my research is ethnography of discourse (including policy) of homelessness, not ethnography of homeless people. The main subjects of my research are people involved in the construction of homelessness as an IMF crisis subject (e.g., policy makers, journalists, academic experts, NGO leaders, and social workers). ${ }^{1}$ Further, I trace neoliberal welfare/labor discourses in relation to homelessness and unemployment policies during the Crisis through the ethnographic observation of changes in the spatial construction of the above two places. The narrative of this chapter: 1) begins with the Square, where homelessness was most visible to the public eye during the Crisis, 2) relays the process of making Seoul City homeless policies and shelter systems under the "Productive welfarism," and 3) moves to the House of Freedom, the largest homeless shelter, created during the Crisis for the purpose of sorting homeless people into "deserving" and "undeserving," based on neoliberal criteria.

\section{The Transformation of the Square}

The 100-year-old Seoul Train Station has been renovated into an ultramodern building. On the New Year's Day [of 2004] the Ministry of Transportation held a ceremony to mark completion in the presence of Prime Minister Ko Kôn (previously mayor of Seoul City)....The renovation took more than three and a half years, and the stations' interior is worthy of an international airport. (Yi Tae-Hee and Kim Kyông-Ho, Hankyoreh, January 3, 2004, 6). ${ }^{2}$

The Seoul Train Station, recently renovated into an international airport-like space, is one of the largest and oldest transit centers in Seoul. It was built in 1925 by the Japanese colonial regime (1919-1945) as a hub for the numerous railroads connecting the Korean Peninsula to Manchuria, the route to the continent (Eckert et al. 1990:269-273). In spite of many repairs, the original station buildings retain the typical architecture of the colonial period with its Renaissance style (Cumings 1997:148-154) —a style that otherwise is very rare due to the nationalist movement to eradicate colonial shadows. ${ }^{3}$ Even after bus and subway became more popular modes of transportation in South Korea, the Seoul Train Station has remained one of the busiest spots in the city as countless bus lines and two major subway lines meet in the station 
area. The Seoul Square has been a place for all kinds of transportation passengers to pass time and meet other people.

Typical of the Square at one time were the scenes of people in transit, frequenting the small businesses that catered to passing travelers. Mobile bars and restaurants (p'ojangmach'a) were set up near bus stops and waiting areas to sell cheap food and alcoholic beverages, such as noodles (kuksu and/or udong), fried vegetables and seafood (temppura), seaweed rolls (kimpap), and Korean sake (soju). Mini food stalls were situated near the bus stops, where bus tokens, gum, candy, and non-alcoholic beverages were sold. Fruit and rice cake vendors set up their pushcarts and baskets at the entrance and on the stairs from the Square to the two subway line stations, or walked among the people in the Square selling their goods. Until the early 1990s, the Square was also the site of mass demonstrations urging political action against authoritarian regimes, including the April Revolution (Sailgu hyôngmyông) in $1960^{4}$ and the April Demonstration Withdrawal (Sôulyôk hoegun) in 1980, the night before the Kwangju Upheaval. ${ }^{5}$

Between $1998^{6}$ and 2001, the Square changed. During this time, the Square became well known as a place where enormous numbers of "IMF homeless" resided. In August 1998, the City estimated that there were two thousand IMF homeless in the Square. In the winter, the number increased to four thousand. When I visited Seoul in 1998, the most common scenes of the Square were rows of homeless people lying on the ground in and around the Square, or in the Station's underground tunnels. It was hard to pass through some of the tunnels because sleeping homeless people were blocking the way. Some used newspapers as protection against the cold, and many were surrounded by empty bottles of Korean sake (soju). While the Square had not presented the image of cleanliness before homeless people began to arrive (sewage from mobile bars and restaurants as well as "night soil" of drunken men were common), during the Crisis, City managers considered the Square to be even filthier due to the growing numbers of homeless people gathering there. In the early morning hours and at noon, long lineups of homeless people waiting for a free meal served by religious groups could be seen in several locations near the Square. In addition to the religious groups, a quasi-governmental welfare agency and at least two civil agencies not aided by the government provided support to the homeless at the Square. The quasi-governmental welfare agency was originally a civil group associated with the Anglican Church. The agency was, during the Crisis, endowed and supported by the Seoul City government and became known first as the Homeless Assistance Center (Nosukcha Chiwonsent'ô) and 
later as the Homeless Rehabilitation Center (Nosukcha Tasisôgi Chiwonsent'ô). ${ }^{7}$ The replacement of "Assistance" with "Rehabilitation" in the title is symbolic of the transformation of welfare regimes from poor relief to a neoliberal workfare regime. The Homeless Assistance Center required homeless people to register for a Homeless Identification Card (Nosukcha K'adû) in order to receive a medical examination. (Most homeless people were missing their Resident Registration Cards, the most important identification document.) Despite offering benefits, such as a free medical examination, the Homeless Identification Card functioned as a means of policing and surveillance: the police had access to the information of the cardholders in the name of "social security." $\mathrm{A}$ free medical examination and treatment attracted the homeless because medical services have been costly for anyone without health insurance, as homeless people commonly were.

One civil agency was the Humanitarian Practice Medical Doctors' Association (Indojuûi Silch'ôn Ûisa Hyôpûihwae), which assessed the health condition of homeless people coming to the Square. ${ }^{9}$ The other was a private welfare agency run by a renowned South Korean TV entertainer, Sim Chôl-Ho. This agency operated a bus called the "Telephone of Love" at the Square. The name is echoing other hotlines, such as "Telephone of Women" for women in a domestic violence situation, "Telephone of Hope" for people affected by a natural disaster. Telephone of Love workers served homeless people who were willing to complete a questionnaire about their family situation, hometown, employment history, and the length of time they were living in the street. The answers were entered into a database of the homeless, which was run independently from the government. In return for this information, the agency provided clothing, toiletries, and nonperishable food.

During the day, many homeless people left the Square as it became busy with passengers or were driven out by station guards. By November 1998, homeless people were not supposed to be in the Square even at night as the Seoul City government made it illegal for street people to be in public places. Instead, they were directed to a homeless shelter called the House of Freedom (which will be detailed in next pages). However, there were still noticeable numbers of homeless staying in the Square, accessing social services and resisting the policy and homeless shelters.

In this context, accompanied by photographers, politicians and upper-level officials paid visits to homeless people to win publicity. Despite the fact that homeless people resided in many public spaces, these visits targeted those staying in the Seoul Square, who soon became the tragic "face" of the Crisis. ${ }^{10}$ 
Mass media (including newspapers, TV specials, soap operas, and novels) often dealt with the subject of IMF homelessness, frequently showing dramatic scenes from the Square. ${ }^{11}$ The homeless were portrayed as the casualties of mass layoffs during the Crisis, encouraging donations and funds for those on the edge of unemployment and homelessness. ${ }^{12}$

My visit in 2001 coincided with the time when mass media and the government frequently reported the Crisis was over. The Square had been rearranged into a huge, clean parking lot for the customers of the train station. I could not find any mobile bars or restaurants (p'ojangmach'a) within the barricades of the parking lot or in the nearby bus stop area. There were only a few remaining fruit vendors with pushcarts or baskets. Before the Crisis, the government had attempted to get rid of mobile bars and street vendors in most of Seoul's public places with the intention to project the image of a clean metropolitan city - an image that could appeal to foreign travelers. However, during the Crisis, there were several massive demonstrations and strong resistance from the owners of the mobile bars. They charged that the government was suffocating the poor working class people who were managing to run marginally profitable businesses in such a dire time. With increasing concern about social instability due to mass unemployment following the IMF bailout, the Seoul City Office withdrew its order to remove the mobile bars in an attempt to stave off further unemployment. Originally, Korean War and Vietnam War veterans and poor families were granted limited permission to run their businesses; however, these regulations changed as economic conditions fluctuated. During the Crisis, it was very common to see college students and unemployed people starting mobile bars in residential areas. In 2001, when the Crisis was officially over, street vending was again restricted. Shifting policy on the street vendors is a good example of how marginal welfare citizens were inconsistently dealt with.

The change seemed linked to the fact that South Korea and Japan were cohosting the Soccer World Cup in 2002. A large new gallery with a souvenir shop promoted this upcoming event through its panoramic glass storefront. Situated prominently in the Square and boasting huge glass windows on three sides, the gallery shop took a full advantage of multimedia effects: it showed off various products with the 2002 World Cup logo and mascot; multiple TV monitors attached to the glass walls aired either commercial advertisements or specially produced films by the South Korean government; and loud speakers blasted out the theme song of the 2002 World Cup, which could be heard at the far edges of the huge Square. 
I now turn to a more extensive analysis of the implementation of new welfare policies - a process which further demarcated the new welfare subject both from the "normal" citizen and from the long-term street living homeless. In order to help understand why the immediate attention to homelessness was a consequence of the Crisis, I contextualize the Crisis in the national history and regional economy.

\section{Background of the Crisis}

The Asian Debt Crisis, known as the largest national disaster after the Korean War as well as the most dramatic downfall from the rapid economic growth, coincided with the election of Kim Dae Jung, the first civilian president from a non-military affiliated political party. Many South Koreans will long remember November 21, 1997-the day when South Korea accepted the terms of an International Monetary Fund (IMF) bailout due to a lack of dollars with which to repay debts to foreign financial institutions. Major newspapers heralded the day as the "second national humiliation day" of Korea (the first being the Japanese colonization of Korea). The IMF bailout was "humiliating" as a reminder of the past humiliation of losing Korean nation to Japanese Imperialism. The national debt crisis has been interpreted as a symbol for giving away the nation to the foreign forces (the IMF supervision for lending the bailout). This "humiliation" sentiment was readily connected to the need for nation-wide cooperation to achieve economic independence in reference of the Repay Debt Movement (Kukch'ae Posang Undong) or the Korean Production Movement (Chosôn Mulsan Changnyô Undong) (Eckert et al. 1990), when after Japan officially colonized Korea in 1910, Korean merchants and affluent nationalists created the Movement to build economic power for supporting nationalist independent movement.

By signing a stand-by agreement with the IMF on December 5th of 1997 the South Korean government agreed to restructure its economic, financial, and government management systems along the liberal free market lines. These measures resulted in the bankruptcy of many large companies and banks and led to large-scale unemployment. The unemployment rate from 1998 to 1999 was between 7 and 8 percent, while the unemployment rate before the Crisis (during the development period) had been quite stable at around 2.5 percent. ${ }^{13}$ Women at home and students who wanted and needed to work were not counted into the unemployment rate calculation. ${ }^{14}$ Therefore, whereas unemployment of casual workers during the Crisis was not immediately rec- 
ognized, the massive layoffs of permanent workers due to the downsizing of amalgamate corporations and to the collapse of small enterprises promptly grabbed public attention and caused enormous social anxiety.

The media expressed concern that many men were on the way to becoming homeless and reported several incidents when fathers either cut off their own fingers or killed their children in order to receive insurance compensation. ${ }^{15}$ One story reported that a young man in his early twenties committed suicide because of overdue wages from his former job; leaving a note describing his pessimistic view of life, he killed himself after several months of homeless life. ${ }^{16}$ The Fund for the National Movement to Overcome Unemployment (Sirôp Kûkpok Kungmin Undong Ponbu Sirôp Kigûm) and other kinds of donations for the Crisis victims targeted only those on the edge of unemployment and short-term homelessness, while leaving out long-term homelessness.

The Crisis should be understood at the level of the Asian regional economy, if not globally. The Crisis began in Thailand on July 2, 1997, when foreign investors retreated from short-term and unhedged loans, fearing a currency hike after the collapse of assets-and-property-market "bubbles." The fear and the tendency to withdraw short-term investments rapidly spread through other Asian countries, including Indonesia, Malaysia, the Philippines, and South Korea (Aslanbeigui and Summerfield 2000). In August 1997, the Kim Young Sam government, the regime prior to Kim Dae Jung's, perceived the Thailand Crisis' impact on South Korea and attempted to reform the financial system toward more transparency to attract foreign investors. However, the Ministry of Finance and Economy, the Bank of Korea, and National Assembly members from both opposition and ruling parties objected to the financial reform in order to protect big conglomerates and national capitalists (Haggard, Pinkston, and Seo 1999:206). By November of the same year, there were too few dollars left in the central bank to repay debts to international short-term lenders. A political scientist reported that when the Kim Young Sam government sent SOS signals to the governments of Japan and the United States, both governments referred South Korea to the IMF for advice (Kim 2000). ${ }^{17}$ Woo-Cumings explains the 1997-1998 East Asian Crisis, in particular South Korea's IMF Crisis, as an illustration of the dilemmas of the developmental state based upon an assumption that it resulted from the state-lead structure of economy.

The [developmental] state can achieve its goal by manipulating the financial structure, but once it does so, it has to socialize risk, either 
through inflationary refinancing (monetary means) of the non-performing loans to bail the firms out, or through expansion of the state equity share of the banks (essentially fiscal means) so as to write off the bad loans. The former is indirect taxation on the populace, and the latter, direct $(1999: 13) .{ }^{18}$

In this context, Kim Dae Jung was elected president at the beginning of the Crisis and his government established the first welfare state while endorsing neoliberalism. Kim Dae Jung's neoliberal approach to welfare was a drastic departure from what Koreans experienced through the developmental state decades, when governmental welfare provisions remained essentially limited to poor relief. Primarily concerned with the maximization of economic growth, Korean developmental state entrusted family and big business as the two pillars of welfare governance. South Korea's successive authoritarian military regimes have used and reproduced a familial and paternalistic social order to prioritize economic development (Han and Ling 1998, Hort and Kuhnle 2000, Moon 1998) and to minimize costs of social policies (Kwon 1999, Tang 2000, Wong 2004). The presumption that families should tend to all familial and personal needs of all family members and ensure their social and individual well-being has been central to the operation of the welfare state in South Korea (Kim, Hahm, and Yoon 1999, Stevens 1998, for Italy and Southern Europe, see Trifiletti 1999). Confucian ethics emphasized filial piety and held adult children responsible for taking care of their old parents, thereby maintaining a social security system through familial support (Chang 1997).

In addition to an emphasis on family responsibility, big conglomerates (chaebôl) have upheld systems of employee allowances to supplement relatively high wages. By offering minimum security of living to their employees, chaebôl were responsible for the welfare of huge number of people in South Korea for the past two decades. Family allowances for married employees, education allowances for children, housing allowances, and owner-driver care allowances covered many needs that might otherwise fall to the state. Thus, the South Korean developmental state not only incubated chaebôl as economic groth engines but also depended on them to provide welfare services, creating a symbiotic relation with big business (Janelli and Yim 1993, Kim C.S. 1992, Kim E.M. 1997, Kim Sunhyuk 2000, Song H. 2003, Yoon B. 1998).

Particularly, in late 1980s white-collar workers' unionization and popularly supported student and labor political activism against anti-military dictatorship prompted chaebol to engage in welfare provision more actively. The 
street rallies and demonstrations of the 1987 democratization movement proved critical for chaebôl as the developmental state built upon military force could not back them as much as before any longer. Compromising their global competitive advantage of cheap labor, chaebôl strategized to appease their workers by expanding benefits and easing their position on wage negotiation with labor unions. These strategies were crucial not only for momentary survival, but also for holding and gaining workers' loyalty to the company and, in the long run, weakening labor unions' leadership (Koo 2001). ${ }^{19}$

In a way, South Korean developmental state was a form of governmentality as many citizens perceived economy-oriented national projects as inevitable, especially with the historical baggage of post-Korean War national poverty and ideological rivalry with North Korea. Thus, citizens endorsed austerity (through movements like New Village Movement, Saemaul Undong, and Anti-Excessive Consumption Movement, Kwasobi Ch'ubang Undong) to various degrees in their home economics as well as in business and national economy (Kwon In Sook 2000, Nelson 2000).

As a criticism of the imbalance of developmental state's weight on economy over welfare, the discourse of "well-being," "social safety nets," and "welfare" began to emerge after the Democratization movement in $1987^{20}$ and strongly amplified during the Crisis with Kim Dae Jung president's primary focus on establishing welfare state that guarantees every citizen's minimum quality of living. As many scholars note, most South Koreans, from lay people to the president, have realized the limitations of developmental regimes that emphasized rapid economic growth at the expense of better human conditions. ${ }^{21}$ In this context, it seems natural that the sudden visibility of homeless people in the Square, an alarming icon of the calamity during the Crisis, is followed up by the Kim Dae Jung administration's decision to designate the population of the homeless as the exemplary subject of the first welfare state that guaranteed a minimum living standard for all citizens. ${ }^{22}$ The administration's need to impress South Korean citizen with the new welfarism was timely matched by the occurrence of the Crisis, and the visibility of homelessness was deemed as a consequence of the Crisis.

However, this unprecedented liberal state action, taking responsibility for the homeless (who used to be population previously unattended, if not neglected, by the state) and treating them as citizens, was the harbinger of neoliberal rationalities of welfare governance as only those employable homeless people were recognized as "proper" citizens eligible for the state-provided basic subsistence (e.g., housing, food, work opportunity). Is the equal treat- 
ment of all social members, including homeless people, by liberal state necessarily in conflict with the neoliberal welfare state logic, which deems only employable homeless people as "deserving" citizens? Or, do the liberal concept of "free individual citizen" and the neoliberal concept of "employable welfare citizen" constitute the shared core of liberalism and neoliberalism in relation to the maintenance and advancement of capitalism? Implications of "free" are ambivalent in terms of citizens' position as "free" laborers. On the one hand, this "freedom" refers to the liberty of workers to sell their labor power to the owners of the means of production and to the freedom of citizens to give their votes within democratic governance to endorse administrators of the state; on the other hand, it marks the abject situation of workers who do not have other means of maintaining their subsistence except "freely" selling their labor power as the only commodity they can sell. Elucidating Marx's theory of capital and labor commodity (1976), Kawashima succinctly sums up the twofold meaning of "free": "free to sell labor power" and "free of the means of subsistence and production" (2005b:618). In that sense, since the emergence of liberal state, the category of "citizen" has been always limited and applied only to the group of people who could work, buy commodities, and pay taxes, thus ultimately contributing to the maintenance of capitalist liberal state along with its class structure (Clarke 2004, Hall et al. 1996). Therefore, it is explanatory to see the interplay of liberal and neoliberal aspects at the launch of the first homeless policy, which discriminated against the unemployable homeless. The complex connection between liberalism and neoliberalism in South Korean history manifests in the collective memories of the Square found in a literary terrain as well as in the very physical spatial history.

\section{Novel, The Square}

The Square is a politically charged trope for South Korean democracy and the ideological position of liberal intellectuals torn between socialism and capitalist liberalism in the divided peninsula. In addition to the fact that the Square has been one of the most popular public places for democratic rallies and demonstrations, the Square (Kwangjang) also served as the title of a controversial novel, The Square (1976), written by Choi In-Hoon. The Square in the novel is a metaphor for public space that contrasts with the cave, a metaphor for private space. The protagonist of the novel, Yi Myông-Jun, contemplates going back and forth between the public space (the Square) and the inner self (a closet or a cave). Yi pursues ideological neutrality between fraudulent lib- 
erality in South Korea and fascist communism in North Korea, ultimately committing suicide on the way to exile in a neutral nation. The historical significance of the novel is twofold. The novel's timeframe encompasses the era beginning with the end of the Japanese colonialism (1930-40s) and ending with the Korean War (1950-53). The novel was written right after the April Revolution (April 19, 1960), the first liberal uprising in the post-war Korea. Although the novel does not mention the April Revolution, critics believe The Square was inspired by the mass demonstrations in the streets and squares of Seoul during the Revolution, and they interpret the novelist's intention as urging South Korean intellectuals to pursue "real" democracy (Hughes 2002).

In this historical context, as will be shown, the Seoul City managers were concerned that the homeless might start an uprising in the Square during the Crisis. Security and policing as major neoliberal technologies (Dean 1999, Donzelot 1979, O'Malley 1996, Ong and Collier 2005) were well exemplified through the City managers' narratives and treatment of homeless people. As I explore the South Korean intellectuals' complicity elsewhere (Song 2005), leftist and liberal movement activists who for the last three decades have loudly protested against the Draconian military state power in public spaces, such as the space of the Square, failed to oppose the (neo)liberalization of the society under the guise of democracy. It is not because they were uncritical of the neoliberalism in theory, but because they were unable to resist pleasant "freedom" of daily life in a capitalist consumer society-in which the liberal idea and the pleasure of "freedom" are obscurely and intricately connected to commodification and exploitation of labor power. The collective memory of the liberal struggles over the last three decades is celebrated in the space of the Square that consolidated the partnership between government organizations (GOs) and non-governmental organizations (NGOs). This kind of rhetoric and practice of partnership between GOs and NGOs was a prominent neoliberal technology that the Kim Dae Jung's administration employed in promulgating social policies, such as homeless policy as it is exemplified in the case of Seoul City in the following pages.

\section{Creation of Homeless Policy in Seoul City}

Here, it would be relevant to delineate narratives of policy-makers (e.g., city managers and experts from academia and civic groups) on the threat posed by the homeless in the streets. First, the homeless discourse becomes a lens revealing a changing paradigm for welfare state ideology, from poor relief under 
developmental regimes towards a workfare regime. In addition, the narratives of Seoul City managers, ${ }^{23}$ which enunciated neoliberal welfarism by privileging "normal" citizens over homeless people, and relatively healthy and employable short-term street-living homeless people over long-term street-living homeless people, compete with the narratives of some experts' liberal ideas on equal rights for homeless citizens. Nevertheless, the City managers' neoliberal standard of "proper" homelessness and the liberal experts' advocacy for homeless people's human rights were in agreement on what is good for homeless people: rehabilitating them into normative socio-economic individuals and familial members (especially into breadwinners in the cases of homeless men).

\section{Debates on the Danger of Homeless People}

Established in June 1998, Seoul City Committee on Unemployment Policies (SCCUP, Sirôp Taech'aek Wiwonhoe) dealt with homeless issues, as the City managers confidently presented their immediate and "efficient" responses to the issues. It was right after the election of Mayor Ko Kôn, supported by the ruling party and well-connected to the Kim Dae Jung administration. His election pledge included a promise to pay special attention to the metropolitan predicament of unemployment and homelessness as a necessary response to the Crisis. On winning the office, the mayor kept his promise by creating the SCCUP and the Commission on Homeless Policy (the Commission, Nosukja Taech'aek Hyôpûihoe), and inviting civil activists and experts to serve as members. Ko Kôn's invitation to civil activists and experts to participate in the emergency machinery as co-decision-makers on City policies, rather than just as consultants, was unprecedented. ${ }^{24}$ More significantly, it corresponded to the presidential course for governing the nation through partnership with civilian groups.

The SCCUP comprised approximately twenty members from civil organizations, universities, and governmental research institutes, in addition to highstatus administrators of Seoul City. The major task of the SCCUP was devising plans to solve mass unemployment problems, mostly by creating jobs through the Public Works Programs. ${ }^{25}$ From the birth of the SCCUP, homelessness appeared to be the most visible and important subject of the Crisis, provoking a great deal of attention from the City, as well as the mass media, giant NGO nationalist networks, like National Movement for Overcoming Unemployment, and central and local governments. The Seoul City Health and Welfare Bureau was the highest unit responsible for dealing with homelessness, which was considered the single most important task of the Health 
and Welfare Bureau. ${ }^{26}$ Other responses to unemployment, such as the Public Works Programs and vocational training programs, were managed by the Seoul City Industry and Economy Bureau. ${ }^{27}$

In addition to the civilian participatory machinery, the mayor designated three vice-mayors, most of whom did not have governmental administrative experience but were politically active in the ruling party. These vice-mayors were directly involved in various aspects of unemployment issues through participation in the SCCUP, with one vice-mayor acting as a chairperson. The three vice-mayors regularly attended the monthly meetings of the SCCUP and appeared to elevate civilians' voices over those of the administrators in the process of policy-making. It was not uncommon to observe the chair of the SCCUP, one of the vice-mayors, reprimanding City managers for not complying with the opinions of the civil members, especially in the first year of the SCCUP. Although it is possible that the vice-mayors were sympathetic to the civilian SCCUP members because the vice-mayors themselves came from outside the bureaucracy, the vice-mayors' show of respect for the civilian members might also have been a calculated action to enhance civilian leaders' trust in the administration and encourage civilian leaders' co-responsibility in liberal governance.

During a SCCUP meeting in September 1998, Mr. Lee, the Head of the Seoul City Health and Welfare Bureau, presented the City's achievements in dealing with the IMF homeless. He stated,

Homelessness is a big problem. It's winter, and they might die of cold (tongsa). It is such a great agony for the City to deal with the increasing numbers of IMF homeless (siljik nosukcha) in public places like the Seoul Train Station Square. The number of homeless amounts to fifteen hundred people. The more homeless, the more spoiled the scenery of the Square, the greater the uneasiness (hyômogam) of the citizens who see them. IMF homeless might be violent to the public or might start a riot against the government, as they are angry due to being deprived by the IMF Crisis [i.e., Asian Debt Crisis]. Therefore, it is dangerous to expose normal civilians to homeless people. We tried to persuade them to go to the homeless shelters that the government [temporarily] provided, but they are not docile. They might die of cold in the street during winter. So, we will not have them staying in the street by making living and sleeping in the streets illegal. After street people are housed in the homeless shelters, finally citizens [i.e., non-homeless people] shall not have to see the 
street people. Already we have housed most of the street people in the Square in the House of Freedom (my emphasis).

Direct services in the Square were mostly provided by temporary recruits from college social work programs, under the supervision of a few middle and lowrank managers. These people did the work of guiding, recruiting, or forcing homeless people to the shelters. Although Mr. Lee, an upper manager, did not work directly with homeless people in the Square, he gave a lively and animated report of the situation of homelessness, as if he himself had experienced the difficulty of working in the Square. In his presentation, Mr. Lee appealed to the SCCUP members by referring to seasonal concerns. In response to his suggestion that the increasing numbers of the homeless in the Square might die of winter cold, most of the committee members showed signs of compassionnodding heads, worried expressions, and concerned whisper.

While some SCCUP members praised the City's efficient management of the much-publicized homeless issue, others cautiously expressed their worries about these City actions. The argument was that the City might neglect the human rights of homeless people through forcible actions toward them. As one committee member uttered, "It sounds like forcing street people out of sight. They are not criminals but victims of the Crisis, just like other citizens who suffer from economic difficulty." This committee member complained because Mr. Lee's narrative tacitly conveyed the negative views of homeless people to justify the immediacy and significance of a homeless policy.

Mr. Lee's narrative mobilizes three rationales for implementing homeless policy: possible death by winter cold (tongsa), an uncomfortable environment (hyômogam) for "normal" citizens, and the potential for violent action (p'okdong ûi wuihômsông). Each references a threat or danger, but to different groups. "Death by winter cold" is the only one of Mr. Lee's rationales that considers a threat to the life of the homeless. The other two rationales- "uncomfortable environment" and "potential for violent action"-indicate a threat from homeless people and the consequent need to protect "normal" civilians. The rationale of making homeless policy for the protection of "normal" civilians explicates the boundary between "deserving" and "undeserving" citizens in two ways: it identifies homeless people as distinct from "normal" civilians. Further, it establishes a need to protect "normal" citizens.

However, in the context of homeless issues, there was a twisted application of the binary categorization between "deserving" and "undeserving" citizens. The homeless, who were considered less "deserving" citizens in comparison to 
normative citizens, may nevertheless be regarded as "deserving" citizens if they were construed as "IMF homeless" (short-term street living people), as differentiated from purangin (long-term street living people). This fragmented categorization of homeless people (as to "deserving" vs. "undeserving" citizens) illustrates a loophole in how the homeless were fabricated as the subjects of IMF-caused unemployment.

In other words, when the government implemented its homeless policy, it was not about a welfare plan for the homeless but about temporary responses to the unemployment crisis after selectively choosing an iconic subject. Therefore, homeless in general were not considered to be "deserving" welfare subjects; only homeless with a "normal" life in the recent past and possibly in the near future were "deserving." This particular construction of the homeless as "deserving" subjects during the Crisis is strongly related to the efforts to conform the welfare system to the new emphasis on the neoliberal ideas of productive welfare-potential for rehabilitation, employability, and normative family membership.

It is notable that most committee members as well as the City managers took for granted that homelessness was an outcome of employment loss and associated with the beginning of the Crisis. Although the SCCUP committee member brought the subject of homelessness as a matter of human rights, he participated in constructing homeless people as victims of the Crisis, rather than acknowledging them as the population that had already been there regardless of the Crisis. However, in spite of the consequences of unwittingly conflating homeless issues with unemployment issues, the SCCUP committee member may have deployed this rhetoric intentionally in order to gain financial support for homeless issues. This would have been an effective strategy because unemployment-related programs were the largest recipients of government finances during the Crisis.

Further, the "potential of violent action" by homeless people was perceived to be threatening state security as well as "normal" civilians. This link is crucial because both political and social stability are indispensable elements of a neoliberal economic polity. A fairly common image of South Korea in the larger world is the picture of mass demonstrations of labor unions, which have been said to hinder South Korean economic growth (Koo 2001). By prioritizing economic stability, if not prosperity, the South Korean government effectively pacified the labor force in the Tripartite Committee of government, chaebôl, and labor force (Kim 2000). In this context, the Seoul City Office was charged with the prevention of any possible civil upheaval against the government by 
the growing number of homeless who gathered in the Seoul Train Station Square, all in the name of protecting homeless people and other citizens.

Through the transformation of the Square and the City managers' narratives, we can see two contradictory sides of the South Korean society at the time: the dispossessed citizens and the services established to support them, on the one hand; and the passengers who still possessed the means to travel through the Square, stopping only momentarily at businesses catering to their needs, on the other hand. The fact that homeless people were driven out of public places during the day and later were entirely prohibited to stay reveals how homeless policy was actually designed to protect "normal" citizens who might be harmed in some way by the presence of homeless people. Narratives of the government managers during this time suggested that homeless people might threaten the safety of "normal" citizens or become violent and stir up riots. The policy spatially segregated people living in Seoul so that the homeless would be removed from the eyesight of the "normal" people who passed through public places.

\section{Categorization of "Deserving" Homeless and Homeless Shelter System}

During the Crisis, two terms evolved to distinguish the "deserving" homeless from the "undeserving" homeless: "IMF homeless" (ai-em-epû nosukcha) ${ }^{28}$ for the former and derogatory purangin for the latter. ${ }^{29}$ According to Mr. Yang, a middle manager dealing with homeless issues in the Seoul City Office,

IMF homeless are people who came to be homeless due to layoffs after the IMF Crisis. They are normal people, not purangin. They have the "intention to rehabilitate (chaehwalûiji)" and the "desire to work (kûlloûiyok)." As opposed to the IMF homeless, purangin have lived in the streets for a long time. Purangin neither want to work, nor do they have the possibility of resuming regular lives (my emphasis).

In fact, such ideas and assumptions were widely circulated by mass media as in the following article in OASIS, a newsletter for unemployed people,

Although 1998 was the time when the national IMF Crisis had all citizens breathing hard and tightening their belts, everybody learned how to cope with difficult situations. But, with the severe economic blow that led to the bankruptcy of many conglomerates, and as well as to the layoffs of many breadwinners and to the breakdown of families, we also 
find an unprecedented number of nosukcha (homeless people). There are two kinds of nosukcha: those originating from the IMF Crisis and purangin-type nosukcha. The purangin-type nosukcha became homeless due to disease, heavy drinking, family breakdown, and unaffordable living expenses. Most of them are in their late forties to early fifties; they have lost their ability to labor as well as their hope for life; and they move between welfare facilities and street living. IMF nosukcha, on the other hand, became homeless due to family breakdown related to the IMF period. They are noticeably young and have the capacity to labor and the desire to work (my emphasis). ${ }^{30}$

One reporter's comments summarize the image that was constructed of an IMF homeless versus a purangin:

Among unemployed homeless people, there are many who used to sleep in the temporary kitchen of a construction site or in restaurant halls downtown. It took at most one or two months for them to end up in the street after becoming unemployed. There are cases when people become homeless immediately after losing employment. However, we should not confuse these people [unemployed homeless people] with purangin who wander because they cannot adjust to a work place and family life. Unemployed homeless are people who would be able to settle down in minutes, as long as they have employment income with which to feed their families, and have a place for their family to spend the night together. (Hankyoreh, September 18, 1998, my emphasis).

Social workers who met and lived with homeless people contested this clear division and challenged the image of IMF homeless as necessarily easily "rehabilitated" and having middle class background. Even the police officer I spoke to in 1998 questioned the distinction: He maintained that before the Crisis, there had been a lot of homeless people in the Square. ${ }^{31}$ Although there were more homeless people living in the Square during the Crisis, he thought most of them were the same kind of wanderers who lived a street life before the Crisis-coming and going as they pleased. Showing his suspicion about sharp differences between recent homeless people and pre-Crisis homeless people, his narrative challenged the newly developed view of the IMF homeless.

Nevertheless, the government officially insisted that homelessness coincided with the massive unemployment following the IMF bailout and built its home- 
less policy upon this unproven premise. The government publicized that it would provide support via work programs and shelters for the IMF homeless, who would soon be rehabilitated. On the surface, government officials denied that homelessness had really existed prior to the Crisis; however, pressure from workers in the field forced them to address the fact that there were homeless people who did not fit the criteria for IMF homeless. Thus, the welfare and shelter systems developed to support primarily short-term street living people who were identified as the IMF homeless, while at the same time, long-term street living people, a.k.a. purangin, were pushed away from public attention.

The homeless shelter system in Seoul, established shortly after the Crisis, consisted of two categories of shelters: Houses of Hope (Hûimang ûi Chip) and the House of Freedom (Chayu ûi Chip). Houses of Hope were small homeless shelters for about ten to thirty homeless people, where only IMF homeless were supposed to stay. The benefits of staying in a House of Hope included being paid, being able to work at Public Works Programs, getting free meals and having a place to sleep. Because of the government's policy to support only IMF homeless, field workers were required to identify IMF homeless and distinguish them from purangin. Thus, the House of Freedom became the first stop for all those entering the shelter system. Here they would be assessed, and those who qualified as IMF homeless would be admitted to the Houses of Hope. Many of homeless people who did not fit to the criteria of the IMF homeless were swinging between the House of Freedom and the street.

\section{The House of Freedom and the History of Pangnim Factory}

When the central state and Seoul City administrations first recognized homelessness as an urgent welfare concern, only the IMF homeless became legitimate welfare subjects - the employability and potential for "rehabilitation" demarcated proper subjects from purangin. This partial legitimization of homeless people is symptomatic of the selective reconfiguration of "appropriate" citizenship within the recently introduced neoliberal welfare ideology. By introducing the way in which quasi-governmental agents were actively mobilized in the implementation of homelessness policy through the City's shelter system, I will elucidate an aspect of neoliberal governmentality whereby the state acts upon non-state agencies. I examine how the dichotomization of Seoul's homeless people was spatially executed and reinforced through City's shelter system, highlighting the transformation of the former Pangnim Factory into the House of Freedom, the biggest homeless shelter, the only 
place where homeless people are fully "free" of obligation and at the same time of opportunities to work.

The House of Freedom is a huge building located in the Kuro industrial area of Seoul. The building, now owned by Seoul City, used to be called Pangnim Factory. It was one of the first and biggest textile factories in the developmental period under the Park Chung Hee regime and once symbolized South Korea's economic success, built on light industry in the 1970s. The 1970s in South Korea were a time when the labor movement began its resistance against the exploitation of (primarily female) laborers by factory owners who were in cahoots with the Park Chung Hee regime, the first military dictatorship, which launched a capitalist developmental state (Chun 2003, Kim S. 1997). ${ }^{32}$ The Pangnim Factory is the site of one of the most memorable labor resistances of the time when the appeal of female laborers for humane working conditions (i.e. an end to unpaid night labor) won wide support among labor and social activists (through Yôngdûngpo Industrial Mission, Yôngdûngpo sanôp sônkyohoe). The wide social support came through consecutive demonstrations against violent police actions, yet, despite their struggles, female laborers were all fired as a result of an alliance between the factory owner and the Park regime.

By the 1980s heavy industry, such as automobile manufacturing, began to represent the South Korea's national prosperity throughout the world (Kim, E. 1997, Cumings 1997) and light industry, such as textiles, had declined to the extent that the Pangnim Factory shut down. The building stood empty for many years before being reopened in 1998 to host thousands of homeless people. Once a symbol of South Korean enterprise, the site, where capitalists wrung dry laborers' lifeblood ${ }^{33}$ and then kicked them out of the workforce, was now providing shelter to multitudes of IMF casualties with the aim of sending them to work. The striking contrasts are observed in the history of Pangnim Factory. A locus for economic prosperity in 1970s, it became a dwelling to the most destitute members of South Korea's citizenry; a place notorious for the exploitation of laborers in the 1970s, now is known as a "shelter" for jobless and homeless people. This change reflects the history of South Korean capitalism, from the rapid economic development stage to neoliberal workfare, in relation to the making and unmaking of "deserving" laborer/welfare state subject. During the so called the economic development era (1960 to late 1980s), it was the major technology of capitalism to employ forceful state, hand in hand with expansive conglomeration, to exploit lowpaid laborers, such as the textile factory workers, and discard them when they were no longer necessary. Then, during neoliberalization (1997 onwards), the 
capitalist technology evolved to subsidize a particular group of the relative surplus population, employable short-term street-living people. This is an example of the commodification of bio-power (Kawashima 2005a), a critical problem of neoliberal governmentality that was neatly articulated by Kawashima who bridged the Foucauldian concept of bio-power as a liberal governing technology and the Marxian concept of commodification of labor power as the fundamental source of capitalist profit-making. Rather than wielding power of death (suppressive power) over the population, liberal states use their power to keep population alive (i.e., bio-power), which can be, if not already have been, essential buttress to capitalist development. In other words, it is the state that is in charge of the security and welfare of different groups of population, including employable surplus population, the supply of whom is crucial for securing the capital's need to control labor through promoting competition among regular workers, precarious workers, unemployed people, and homeless people. Therefore, the Pangnim Factory is a window that shows the history of the South Korean state power, which adjusted its ways of dealing with labor population (or welfare citizenship as it is linked to the labor market) from suppressive to benevolent, while consistently maximizing capitalist interests.

I visited the House of Freedom in 1999 and arranged an interview with Mr. $\mathrm{Ku}$, a quasi-governmental employee who ran the shelter and the Homeless Rehabilitation Centre (HRC), a mid-level civil agency mandated by the government to assign homeless people to the Houses of Hope. In the management office where I waited, I sat with a few relatives of homeless residents. Many social work college students went in and out of the office, making notes on the board or looking for visiting family members. Ceaseless announcements over a loud speaker kept requesting that social workers look for several homeless people to provide counseling, or to arrange meetings with visiting family. Some broadcast announcements requested that social workers from the Houses of Hope pick up those who passed as IMF homeless.

The House of Freedom's former life as a giant textile factory made it spacious, but its industrial past and its long vacancy had left the walls and floor ugly and bare, giving it an empty and chilly feeling. The incessant announcements sounding through the air of the old factory building reminded me of an old train station lobby, where people come and go quickly or sojourn shortly, much like the Seoul Train Station waiting room. The high ceilings and empty space caused the announcements to echo deafeningly through the air. These echoing sounds might have felt familiar to some street people, who 
were used to staying in various train stations. The House of Freedom, thus, recalled the Seoul Train Station, but with the added dimension of being legitimized as a space in which homeless people were institutionalized and sorted into governable or ungovernable welfare subjects.

Mr. Ku arrived to our meeting late as he had been held up in an emergency meeting regarding violence among the residents of the House of Freedom. He introduced himself as a once-devoted student activist in the early 1980s and seemed to feel more comfortable talking with me after discovering that I was also involved in the student movement during the 1980s, though I was his junior in terms of generations of activists. ${ }^{34}$ When the subject turned to the IMF homeless, Mr. Ku provided clear insights into the problematic construction of the welfare subject. He attested that the government had made an error in ordering social workers to distinguish the IMF homelessness from long-term homelessness, indicating that the distinction was not so clear and that the rehabilitation of any homeless people would not be accomplished soon, as the government had promised:

This is a hell of a battle field (asurachang). Originally, we prepared to receive 300 street people in the House of Freedom, but on the opening day 1200 people crowded into this building. We don't have enough staff to control them. But the more problematic aspect is the wrong direction of homeless policies... The City [managers] might think that they have successfully taken care of homeless issues since they have perfectly managed to hide homeless people from the eyes of the citizenry. However, it is naïve of the City managers to think that IMF homeless will immediately return to society if only the City offers them a place to sleep and a temporary job for the winter. The problems of homelessness have only just begun.

In order to analyze the fundamental problems of producing homeless and to categorize them in an appropriate way, it is necessary to counsel them in depth for a long time and to conduct qualitative research. But there are few specialists of homeless issues, and any research budget is the first to be cut by the governments, nowadays. This is probably because the City doesn't consider the homeless as a regular welfare subject.

According to $\mathrm{Mr}$. $\mathrm{Ku}$, this was a meaningful time for him and other graduate students of social work to study homelessness as a newly emergent social 
welfare subject. However, in addition to his enthusiasm for the possible academic contribution, he also had pragmatic concerns about the homeless management issues. One big problem for him was the government's requirement that the HRC identify the IMF homeless and provide services only for them. He said that there were many homeless people who had been in the street and in public places like the Seoul Train Station for a long time-more, in fact, than people who had recently begun to live in the street. So, the requirement to remove all the homeless from the City's public places to the HRC was in tension with City's intention to provide services only for the IMF homeless. Mr. Ku said it was difficult to distinguish the IMF homeless from purangin and indicated that the problems ran much deeper:

The government might reduce the number of homeless people through providing short-term benefits for them-shelters and work opportunity at the Public Works Program—but those benefits rendered an explosion of the population residing in these shelters, and now the governments face the trouble of managing them. Homeless problems should be solved with a long-term plan. The benefits for people who receive governmental subsidy for livelihood are less than those for homeless people. So, the House of Freedom intentionally doesn't provide a benefit for the Public Works Program [different from the Houses of Hope]. But, without the benefit of the Public Works Programs, homeless people tend not to come to homeless shelters.

At the one-year celebration symposium of the HRC, Mr. Ku distanced the HRC from the governmental policies and representation of homeless issues. ${ }^{35}$ He announced that policies designed for the IMF homeless were limited in their ability to address the needs of the rest of homeless people and revealed shocking statistics. He maintained that only twenty percent of the homeless population could be classified as IMF homeless, contesting the governmental premise that homelessness coincided with the economic crisis.

Mr. Ku insisted, "Homeless problems in our society have been latent because of a lack of social safety net and meager welfare system. Therefore, it is necessary to reexamine the direction of homeless policy in a long-term plan." This public announcement was a blow to the government, which had attempted to dismiss the historical and structural aspects of homelessness, for which government could be responsible, by underlining the temporary nature of homelessness as caused by the Crisis. The HRC's presentation of statistics, traditionally the 
authoritative domain of bureaucracy, was especially devastating. Governmental homeless policies created the IMF homeless as the only legitimate welfare subject deserving of public services in the era of the Crisis. Purangin were othered as policies were predicated upon the assumption that homelessness emerged only due to the Crisis. These assumptions were contested by field workers like Mr. Ku and the policeman who had been in the Square over years.

While the Kim Dae Jung government's welfare state conveyed an image of successfully "guaranteeing the minimum standard of living" through its inauguration of homeless measures, the Kim administration's "guarantee" was not of the state's role as provider to all homeless people, but of the state as mediator that targets the homeless people whose employability is proven. The Kim administration aimed to mobilize self-governable welfare citizens, not dependant on the state- a goal that I identify as a product of the emergence of neoliberal welfarism in South Korea. Pursuit of disciplining welfare citizenship toward workfare or post-welfare citizenship has not impacted much on the amelioration of disenfranchised people, such as long-term street-living homeless people, even when a homeless policy was systematically implemented for the first time in Korean history. The changes in spatial arrangements and population of the Square and of the House of Freedom embody socio-political construction of "deserving citizenship," achieved through the distinction of the homeless from "normal" citizens, and of the IMF homeless from purangin. Further, the history of the building, which hosted the House of Freedom and the Pangnim Factory reflects the shift in the technology of South Korean capitalist development towards neoliberal governmentality through bio-politics of commodified labor power: from the exploitation of cheap labor to subsidization of surplus population.

\section{ACKNOWLEDGEMENTS}

An initial draft of this paper was presented in "Constructed Places, Contested Spaces: Critical Geography in Korea," University of California, Los Angeles, May 14-16, 2004. I am grateful to Timothy Tangherlini and Sallie Yea, the organizers of the conference, for the opportunity. I would also like to thank for a generous support from the Connaught Fund and the Department of East Asian Studies at the University of Toronto, and to Linn Clark, Olga Fedorenko, Roy Richard Grinker, Ken Kawashima, and two anonymous reviewers for their helpful comments and suggestions. 


\section{ENDNOTES}

'I would like to clarify why I purposefully do not include homeless people's own narratives. I found it very problematic to include homeless people as actors of making the particular discourse of homelessness during the IMF crisis. It is partially because homeless people were not part of making homeless policy. Further, recruiting homeless people as short term interview objects would be unethical because most of them are unwilling to expose their lives to others (see my endnote number 8 for the particular context to hide their personal information and background due to policing and harassment). I think it would be less respectful to homeless people if I pursued collecting their narratives just for the sake of making them a part of my research. Therefore, my effort to find out their own stories was limited due to the focus as well as my ethical standpoint.

${ }^{2}$ All translations are my own.

${ }^{3}$ It was designed in 1925 by C.K. Larandei, a German architect (Seoul, Jung-gu Culture and Tourism, "Seoul Station Building," http://tour.junggu.seoul.kr/english/culture/culture_view. php?idx=15).

The way that Renaissance style architecture symbolizes Japanese colonialism in Korea is a good example of how in some East Asian nations the Western European imperial cultures were mediated by Japanese colonialism, rather than experienced through direct colonization by Western European nations. Therefore, idealization of European or Western cultures is a transposed and doubly colonized product in that Japanese colonialism emulated and competed with the colonial nations in Western Europe and North America.

${ }^{4}$ It was the first mass demonstration against the state authority causing human casualty since the Korean War.

${ }^{5}$ This biggest state-led massacre of civilians took place under the Chun Doo Hwan military regime and was provoked by accusation of communist riot. It was executed with the tacit approval of the US Pacific military command, which has controlled the South Korean military force since the Korean War (Shin and Hwang 2003).

${ }^{6}$ Although the Crisis began in November 1997, the real impact of the Crisis was observed mostly from 1998.

${ }^{7}$ The Homeless Rehabilitation Center (HRC) was established as a compromise after Seoul City spent several months attempting to deal with homeless issues (Homeless Rehabilitation Center 1998; Seoul City Committee Meeting for Unemployment Policy September 1998; Park Kûn-Ae, Hankyoreh, September 17, 1998).

${ }^{8}$ There were incidents when the police used the Homeless Identification Cards to inquire into the background of the cardholder when after a runaway criminal. Through Social workers who assisted street people in temporary homeless shelters told me that receiving and carrying a Homeless Identification Card was a very degrading experience for many homeless people and further damaged their trust in shelter workers who requested that homeless carry the card. It is at the heart of liberal and neoliberal governmentality that social security and social responsibility are the other side of social rights and that the rationality of social security is not limited to control but extended to calculation of the possible and policing of the probable (Gordon 1991:35-41, Foucault 2003).

${ }^{9}$ Park Yong-Hyôn, Hankyoreh, March 18, 1999.

${ }^{10}$ For example, Ko Kôn, the Mayor of Seoul, stopped by on September 21, 1998 (Kwon HyôkCh'ôl, Hankyoreh); Kim Po-Im, the Minister of Health and Welfare, visited on June 2, 1998 (Ahn Ch'ang-Hyun, Hankyoreh); and Ch'a Hûng-Bong, the next Minister of Health and Welfare came by on July 21, 1999 (Sôn Tae-In, Tong-ah Ilbo). Also, there were visitors from the ruling party and the opposition party. It is notable that homeless people in the Square complained when reporters took pictures of them for political use. 
${ }^{11}$ Road Movie (Lodû mubi), directed by Kim In-Sik, is a South Korean feature film released in 2002 about homelessness and same-sex relationship between men with many scenes taking place in the Square.

${ }^{12} \mathrm{Yi}$ Won-Jae reports that there were even donations from the transnational Korean community in the U.S.A. (Hankyoreh, April 15, 1998).

${ }^{13}$ The total population of South Korea is about 40 million, and the workforce population was about 10 million before the Crisis. After the Crisis hit, 1.5 million workers lost their jobs in one year (UNDP 1999: 40). In 1997 real GDP grew by 5 percent, while in 1998 it dropped by 5.8 percent. In 1996 and 19978.5 percent of South Koreans lived in poverty, but in 1998 this number reached 12 percent. The unemployment rate soared from 2.5 percent in 1997 to 7.3 percent in 1998, and the real wages plummeted by 10 percent between 1998 and 1999 (World Bank 2000, UNDP 1999).

${ }^{14}$ Unemployment rates reported by the National Statistical Office bring a controversial issue because it appears as if there was no unemployment problem before the Crisis. However, Cho Sun-Kyung argues that the unemployment rate was already almost 20 percent even before the Crisis because irregular/casual workers and discouraged unemployed workers were not counted (1999).

${ }^{15}$ No Hyôn-Sôk, Yi Hyôn-Uk, \& Hwang Sang-Ch'ôl, "Tragedy of Tearing Off Poor Family on the Edge” (Pyôrang kkût pin'gonch'ûng kachok jjin nûn ch'amgûk), Hankyoreh, September 13, 1998.

${ }^{16}$ Sohn Won-Je, Hankyoreh, December 27, 1999.

${ }^{17}$ It is interesting to note that Joseph Stiglitz, former chairperson of the World Bank, also criticized the role of the international financial institutes, in particular of the IMF $(2000,2002)$. Regardless of the different explanations about the origin of the Asian Debt Crisis (whether it was caused by intra-national weakness or by extra-national push, and whether it was voluntarily or involuntarily), it seems that many Asian regimes, including that of Kim Dae Jung, to various degrees decided to change both the reality and international image of their protectionist economies and establish neoliberal state policies during the Crisis.

${ }^{18} \mathrm{On}$ the other hand, Kim Eun Mee (1999) explains the impact on chaebôl with her theory of balance of power dynamics between (developmental) state and business. According to her, the South Korean developmental state began pursuing economic growth as the priority. In terms of the relationship between the state and business, the state was dominant in the beginning, then the relations came to be symbiotic, achieving the common goal of making profits. But finally, after the economic growth arrived at a satisfactory stage, business came to contest state power with growing independence; the developmental state lost the legitimacy of its economic intervention and began to make efforts to reduce state power, moving towards democratic and limited state. Kim considers chaebol in South Korean post-War period and Zaibatsu in Japanese pre-World War II period as not identical in terms of discrepant timing, bank-ownership (Zaibatus had, but not chaebol has), degree of state regulation and intervention. However, Meredith Woo-Cumings (1999) and Bruce Cumings (1999) consider big business as a common character between Japan, Korea, Taiwan in the realm of Japanese colonial impact.

${ }^{19}$ It might not be a coincidence finding a similarity between the emergence of welfare society in Britain at the pivotal period of industrialization and that of South Korean welfare system in the big enterprise. Regarding the origin of welfare state, some scholars interpret it as another trick of capitalism to disguise its exploitive face (Flora and Heidenheimer 1987). Ong also considers welfare state as identical with capitalist modern state (1999).

${ }^{20}$ The heat of the Democratization Movement in 1987 created the opportunity to voice a desire for more civil "freedoms," thereby improving quality of life. Examples include the unionization of white-collar workers (Koo 2001); the expansion of environmental and civil rights' movements (Cho H.-Y. 2000); the mainstreaming of the women's movement (e.g., 
anti-domestic violence movements) (Moon 2002, Park 1999, Yoon B. 1998); the increased tension between heightened domestic consumption and moral projects to prevent excessive consumption (Nelson 2000); and the emergence of sexual identity politics (Seo 2001).

${ }^{21}$ I appreciate to an anonymous reviewer's suggestion on providing more background of lack of attention to welfare during the developmental state.

${ }^{22}$ See Song, forthcoming, regarding complicated politico-economic context of the appearance of neoliberal welfarism when Kim Dae Jung established the first welfare state in South Korea as soon as he was elected in the beginning of the Crisis.

${ }^{23}$ The context of working environment for the Seoul City managers, including those responsible for homeless policy, is elucidated in Song 2004.

${ }^{24}$ Some experts participated in both the SCCUP and the Commission. Their perspective was that even though the City made the Commission and the SCCUP almost simultaneously, they had different roles. The Commission was not a decision-making body; rather, it was a group of mostly religious leaders who managed homeless shelters entrusted to them by the City. In contrast, the SCCUP was actively engaged in decision-making by the mayor's office, in spite of strong resistance from the body of administrators. As a consequence, monitoring and correctional advice for the City-funded homeless shelters was more effectively executed through the SCCUP than through the Commission, even though the latter was more fully responsible for homeless issues in the City.

${ }^{25}$ In its first year, the SCCUP developed projects of larger scope than merely allocating funds for new Public Works Programs. For example, the SCCUP embarked on grand projects establishing Employment Information Bank (Ch'iôp Chôngbo Ûnhaeng) and a Youth Cultural Center (Ch'ôngsonyôn Munhwa Sent'a) garnering extra-funding from the City administration.

${ }^{26}$ The practical implementation of the homeless policy was on the Seoul City Homeless Policy Division under the Health and Welfare Bureau. In general, this division is the practical executive branch of the City administration.

${ }^{27}$ In terms of practical management of other unemployment issues, the Seoul City Industry Policy Division and the Seoul City Unemployment Policy Division-under the Seoul City Industry and Economy Bureau-administrated the Public Works Program. The Seoul City Labor Policy Division-under the Seoul City Industry and Economy Bureau-managed the vocational training program.

${ }^{28}$ There are two variations of appellation for the IMF homeless: ai-em-epû shiljik nosukcha, which translates as "IMF laidoff homeless;" and ai-em-epû hyông nosukcha, which means "IMF-style homeless." Nosukcha is a neutral term for a street living person, which became popular only during and after the Crisis although the word had existed as a rare literary expression.

${ }^{29}$ Song Ch'ang-Sôk Hankyoreh 21, April 1, 1999; Kang Sôk-Un, Hankyoreh, April 17, 1998.

30"Perspectives on Nosukcha," OASIS, 11 December 1998.

${ }^{31}$ Interestingly, he did not use any particular word to indicate homeless people, nor the recent categories "IMF homeless" (nosukcha), neither longstanding purangin. Rather, he used general indicators for persons, chô saramdûl (the people or these people).

${ }^{32}$ This is the context in which textile worker Chon Tae-II, committed self-immolation by fire demanding to end labor exploitation in Pyônghwa market (November 13, 1970). His sacrifice is commemorated as a cornerstone of the South Korean labor movement history (Chun 2003, Cumings 1997).

${ }^{33}$ I thank an anonymous reviewer's suggestion of this expression.

${ }^{34}$ In the context where the welfare state was introduced to implement neoliberal policies in the late 1990s, it is interesting to observe how generations of student activists from the 1980s became leaders of NGOs and got involved in the government-initiated implementa- 
tion of welfare society. The change of social reformists' rhetoric from anti-dictatorship to civil society provides a background to the amplification of neoliberal society in South Korea (Song 2005).

35Sôh Chông-Kwôn, Segye Ilbo, September 14, 1999.

\section{REFERENCES}

Anagnost, Ann. 2004. "The Corporeal Politics of Quality (Suzhi)." Public Culture 16(2):189208.

Aslanbeigui, Nahid, and Gale Summerfield. 2000. "The Asian Crisis, Gender, and the International Financial Architecture.” Feminist Economics 6(3):81-103.

Barry, Andrew, T. Osborne, and N. Rose, eds. 1996. Foucault and Political Reason: Liberalism, Neo-Liberalism, and Rationalities of Government. Chicago: University of Chicago Press.

Burchell, Graham, C. Gordon, and P. Miller, eds. 1991. The Foucault Effect: Studies in Governmentality. Hemel Hempstead: Harvester Wheatsheaf.

Chang, Kyung-Sup. 1997. "The Neo-Confucian Right and Family Politics in South Korea: The Nuclear Family as an Ideological Construct." Economy and Society 26(1):22-42.

Cho Hee-Yeon (Cho, Hui-yon). 2000. "Democratic Transition and Changes in Korean NGOs." Korea Journal:275-304.

Cho Sun-Kyung. 1999. Yôsônghaego ûi silt'ae wa chôngch'aek kwaje (Women's Lay-Off and Suggestions for Policy Making). Seoul: The Presidential Commission on Women's Affairs,

Choi, In-Hoon. 1976[1960]. Kwangjang (The Square). Seoul: Munhak kwa chisôngsa.

Chun, Soonok. 2003. They Are Not Machines: Korean Women Workers and Their Fight for Democratic Trade Unionism in the 1970s. Atarts, UK: Ashgate

Clarke, John. 2004. Changing Welfare Changing States: New Directions in Social Policy. London: Sage Press

Cumings, Bruce. 1997. Korea's Place in the Sun: A Modern History. New York: W.W. Norton \& Company.

1999. "Webs with No Spiders, Spiders with No Webs?" In M. Woo-Cumings, ed., The Developmental State, 61-92. Cornell Studies in Political Economy. Ithaca: Cornell University Press.

Dean, Michell. 1999. Governmentality: Power and Rule in Modern Society. London: Sage Publications.

Donzelot, Jacques. 1979. The Policing of Families. R. Hurley, trans. New York: Pantheon Books.

Eckert, Carter J., et al. 1990. Korea Old and New: A History. Massachusetts: Harvard University Press

Flora, Peter, and Arnold J. Heidenheimer, eds. 1987. The Development of Welfare States in Europe and America. New Brunswick: Transaction Books.

Foucault, Michel. 1990. History of Sexuality I: An Introduction. New York: Vintage Books.

1991. "Governmentality." In G. Burchell, C. Gordon, and P. Miller, eds., The Foucault Effect: Studies in Governmentality, 87-104. Chicago: The University of Chicago.

2003. "Society Must Be Defended": Lectures at the College de France, 1975-76.

Translated by David Macey. New York: Picador. 
Gordon, Colin. 1991. "Governmental Rationality: An Introduction." In G. Burchell, C. Gordon, and P. Miller, eds., The Foucault Effect: Studies in Governmentality, 1-52. Chicago: The University of Chicago.

Haggard, Stephan, Daniel Pinkston, and Jungkun Seo. 1999. "Reforming Korea Inc.: The Politics of Structural Adjustment under Kim Dae Jung." Asian Perspective 23(3):201-235.

Hall, Stuart. 1984. "The State in Question." In G. McLennan, D. Held, and S. Hall, eds., The Idea of the Modern State, 1-28. Milton Keynes: Open University Press.

Hall, Stuart et al., eds. 1996. Modernity: An Introduction to Modern Societies. Cambridge: Blackwell Publishers.

Han, Jongwoo, and L.H.M. Ling. 1998. "Authoritarianism in the Hypermasculinized State: Hybridity, Patriarchy, and Capitalism in Korea." International Studies Quarterly 42:53-78.

Hort, Sven E. 0, and Stein Kuhnle. 2000. "The Coming of East and South-East Asian Welfare States." Journal of European Social Policy 10(2):162-184.

Hughes, Theodore. 2002."Reconstucting the 'Revolution' and the Specter of Coloniality: Ch'oe In-Hun's The Square and Voice of the Governor-General." In The Korea Workshop 2002-2003, University of Illinois, Urbana-Champaign.

Janelli, Roger L., and Dawnhee Yim Janelli.1993. Making Capitalism: The Social and Cultural Construction of a South Korean Conglomerate. Stanford: Stanford University Press.

Jessop, Bob. 1994. "The Transition to Post-Fordism and the Schumpeterian Workfare State." In R. Burrows and B. Loader, eds., Towards a Post-Fordist Welfare State?, 13-37. London and New York: Routledge.

Kawashima, Ken C. 2005a. "Towards a Thinking Against Biopolitical Commodification of Labor Power" a paper presented in the conference, Nation, Culture, New Economy in East Asia, University of Washington, Seattle, USA (April 23), a chapter submitted to an edited book with other participants.

2005b. "Capital's Dice-Box Shaking: The Contingent Commodifications of Labor Power." Rethinking Marxism 17(4):609 - 626

Kim, Choong Soon. 1992. The Culture of Korean Industry: An Ethnography of Poongsan Corporation. Tucson: University of Arizona Press.

Kim, Byung-Kook. 2000. "The Politics of Crisis and a Crisis of Politics: The Presidency of Kim Dae-Jung," Korea Briefing 1997-1999. K. Oh, ed. Pp. 35-74. New York: M.E.Sharpe.

Kim, E.H., H.H. Hahm, and T.L. Yoon, eds. 1999. Cultural Analyses of Korean Economic Crisis. Seoul: Hyônmin sisûtem.

Kim, Eun Mee. 1997. Big Business, Strong State: Collusion and Conflict in South Korean Development, 1960-1990. Albany: State University of New York Press.

Kim, Seung-Kyung. 1997. Class Struggle or Family Struggle?: The Lives of Women Factory Workers in South Korea. Cambridge: Cambridge University Press.

Kim, Sunhyuk. 2000. The Politics of Reform in South Korea: The First Year of the Kim Dae Jung Government, 1998-1999. Asian Perspective 24(1):163-185.

Koo, Hagen. 2001. Korean Workers: The Culture and Politics of Class Formation. Ithaca and London: Cornell University Press.

Kwon, Huck-ju. 1999. The Welfare State in Korea: The Politics of Legitimation. New York: St. Martin's Press.

Kwon, In Sook. 2000. "Militarism in My Heart: Women's Militarized Consciousness and Culture in South Korea." Dissertation. Clark University, Women's Studies.

Li, Tania. 2002. "Government through Community in the Age of Neo-Liberalism," Presentation at Agrarian Studies, Yale University. 
Marx, Karl. 1990[1976]. Capital: A Critique of Political Economy Volume I. Ben Fowkes, trans. New York: Penguin Books.

Mitchell, Katharyne. 2004. Crossing the Neoliberal Line: Pacific Rim Migration and the Metropolis. Philadelphia: Temple University Press.

Moon, Seungsook. 1998. "Begetting the Nation: The Androcentric Discourse of National History and Tradition in South Korea." In E.H. Kim and C. Choi, eds., Dangerous Women: Gender and Korean Nationalism. New York: Routledge.

2002. "Carving Out Space: Civil Society and the Women's Movement in South Korea." The Journal of Asian Studies 61(2):473-500.

Nelson, Laura. 2000. Measured Excess: Gender, Status, and Consumer Nationalism in South Korea, New York: Columbia University Press.

O’Malley, Pat. 1996. "Risk and Responsibility." In A. Barry, T. Osborne, and N. Rose, eds., Foucault and Political Reason: Liberalism, Neo-Liberalism and Rationalities of Government, 189-208. Chicago: The University of Chicago Press.

Ong, Aihwa. 1999. Flexible Citizenship: The Cultural Logics of Transnationality. Durham: Duke University Press.

Ong, Aihwa and Stephen J. Collier. 2005. Global Assemblages: Technology, Politics, and Ethics as Anthropological Problems. Malden, MA: Blackwell Publisher.

Park, Kyung-Ae.1999. "Political Representation and South Korean Women." The Journal of Asian Studies 58(2):432-448.

Peck, Jamie. 2001. Workfare States. New York: Guilford Press.

Peck, Jamie, and Nik Theodore. 2001. "Exporting Workfare/Importing Welfare-to-Work: Exploring the Politics of Third Way Policy Transfer." Political Geography 20:427-460.

Rose, Nikolas. 1990 Governing the Soul: The Shaping of the Private Self. London: Routledge 1999. Powers of Freedom: Reframing Political Thought. Cambridge, UK: Cambridge University Press.

Seo Tong Jin. 2001. "Mapping Vicissitude of Homosexual Identities in South Korea." Journal of Homosexuality 40(3/4):65-80.

Shin, Gi-Wook and Kyung Moon Hwang. 2003. Contentious Kwangju: The May 18 Uprising in Korea's Past and Present. Lanham: Rowman and Littlefield.

Song, Ho Keun. 2003. "The Birth of a Welfare State in Korea: The Unfinished Symphony of Democratization and Globalization." Journal of East Asian Studies 3(3):405-432.

Song, Jesook. 2004. "Understanding the Neoliberal Value of Human Capital: South Korean Government Managers under Social Policy Reform 1997-2001." Canadian Asian Studies Association 25 $5^{\text {th }}$ Anniversary Conference, Calgary: October 7-10.

2005. "Are Liberalism 0.K. but Not Neoliberalism?: Intellectuals' Agency in Liberal Social Governance," a paper presented in the conference, Nation, Culture, New Economy in East Asia, University of Washington, Seattle, USA (April 23), a chapter submitted to an edited book with other participants.

forthcoming. "'Family Breakdown' and Invisible Homeless Women: Neo-liberal Governance during the Asian Debt Crisis in South Korea, 1997-2001." Positions: East Asia Cultures Critique. 38 pages.

Stevens, Carolyn. 1998. On the Margins of Japanese Society. London: Routledge

Stiglitz, Joseph. 2000. "What I Learned at the World Economic Crisis: The Insider." The New Republic On Line. http://www2.gsb.columbia.edu/faculty/jstiglitz/download/opeds/ What_I_Learned_at_the_World_Economic_Crisis.htm.

2002. Globalization and Its Discontents. New York: W.W.Norton \& Company. 